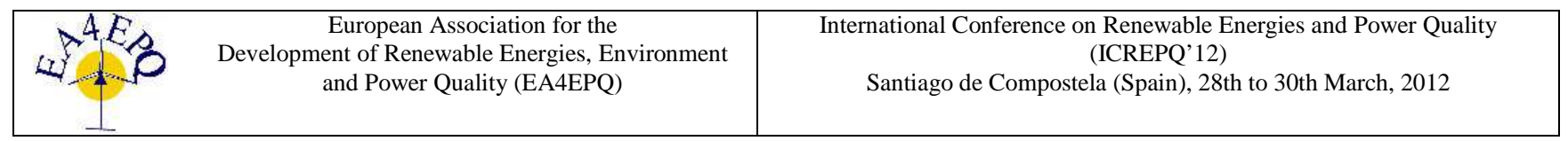

\title{
Total integration of renewable and fossil energy aiming to a clean and sustainable energy system
}

\author{
D.G. Pinatti ${ }^{1}$, R.A. Conte ${ }^{1}$ \\ ${ }^{1}$ Department of Materials Engineering \\ Escola de Engenharia de Lorena, Sao Paulo University \\ Polo Urbo Industrial P.O.Box 116 -12600-000 Lorena, SP (Brazil)
}

Phone/Fax number: +0055 12 31599903/12 31533006, e-mail: pinatti@demar.eel.usp.br, rosaconte@ demar.eel.usp.br

\begin{abstract}
This paper presents a new concept of total integration of renewable and fossil energies (TIRFE), represented by an octagonal structure of all sources, vectors of transmission and optimization of consumption, aiming a clean and sustainable energy system. The main TIRFE technologies are: cogeneration of $\mathrm{H}_{2}$ and electric energy (EE) by biomass gasification in supercritical water integrated with a thermoelectric unit $\left(\mathrm{H}_{2}\right.$-BGSCW/TEU); use of $\mathrm{H}_{2}$ from biomass in oil refinery processes for production of light and clean derivatives; supply of $\mathrm{H}_{2}$ deficiency for methanol production from coal; carbon sequestration by a basket of technologies (exhausted P\&G wells, underground saline aquifers, forests and stockpile of cellulignin-CL-produced from forest residues); use of $\mathrm{H}_{2}$-BGSCW/TEU as district CHP with photovoltaic panels for $\mathrm{EE}$, including electric car battery recharge; optimization of energy consumption by verticalization of the cities replacing low strength materials (bricks and common cement) by high performance concrete with addition of silica from rice husk. TIRFE helps to solve key problems of $\mathrm{H}_{2}$-BGSCW/TEU, such as materials, energy recovery, plugging, corrosion, economics and energy security for the first generation of plants, and organizes the development for the second generation. TIRFE can be incrementally implanted in existent and new cities.
\end{abstract}

\section{Key words}

Energy integration, sustainability, hydrogen, biomass gasification, supercritical water.

\section{Introduction}

Renewable energy is unsufficient to deal with the demand, and fossil energy is pollutant. This paper presents a new concept of total integration of renewable and fossil energy (TIRFE) aiming to a clean and sustainable energy system. The best way to present TIRFE is to introduce the octagonal structure of the main energies (Fig.1), which is divided into three regions: consumption (inner octagon), vectors/products (intermediate), and sources (outer octagon). The main sources are coals (mineral, shale oil, tar sands), P\&G, energy forest, herbaceous (sugarcane, grass), oleaginous plants, excretions, microalgae, solar (photovoltaic, thermal), fluids (hydraulic, eolic, oceanic), nuclear, and residues (organic/inorganic). TIRFE allows simultaneous development of a clean and sustainable energy system with optimization of consumption in residential, commercial and industrial sectors.

The main characteristics of TIRFE are: (a) to allow greening of the world [1] to be used for production of $\mathrm{H}_{2}$ at competitive costs (US $3.00 / \mathrm{kg}$ ) by gasification of biomass in supercritical water [2]-[6] integrated with a thermoelectric unit $\left(\mathrm{H}_{2}\right.$-BGSCW/TEU) that can be scaled from pilot plant (distributed $\mathrm{H}_{2} / \mathrm{EE}$ ) up to large production; (b) besides present market of $\mathrm{H}_{2}$ $\left(\mathrm{NH}_{3} /\right.$ fertilizer-53\%, hydrocracking and hydrotreatment in the oil refinery-28\%; methanol-11\%, compressed $\mathrm{H}_{2}-8 \%$ ), new markets will be stimulated: $\mathrm{H}$-Bio process for biodiesel with absence of effluents and glycerine[7], fuel cells, methanol production from carbonaceous fuels and $\mathrm{CO}_{2}$ [8], and $\mathrm{H}_{2}$-duct operating at 2-10 $\mathrm{MPa}$ for $\mathrm{H}_{2}$ transportation and storage of energy; (c) at the urban neighborhood the $\mathrm{H}_{2}$-BGSCW/TEU can operate as a CHP unit (combined heat and power) using various kinds of fuels (MSW-municipal solid waste, biomass pellets, etc.); (d) $\mathrm{CO}_{2}$ from $\mathrm{H}_{2}$-BGSCW/TEU is clean and has purity to be used in photobioreactors for microalgae growth for oil (biodiesel) and protein production[9].

\section{Integration by cleaning of oil derivatives by $\mathrm{H}_{2}$ from biomass, of vegetable oils by H-Bio process, of coal by a basket of technologies and GHG retention}




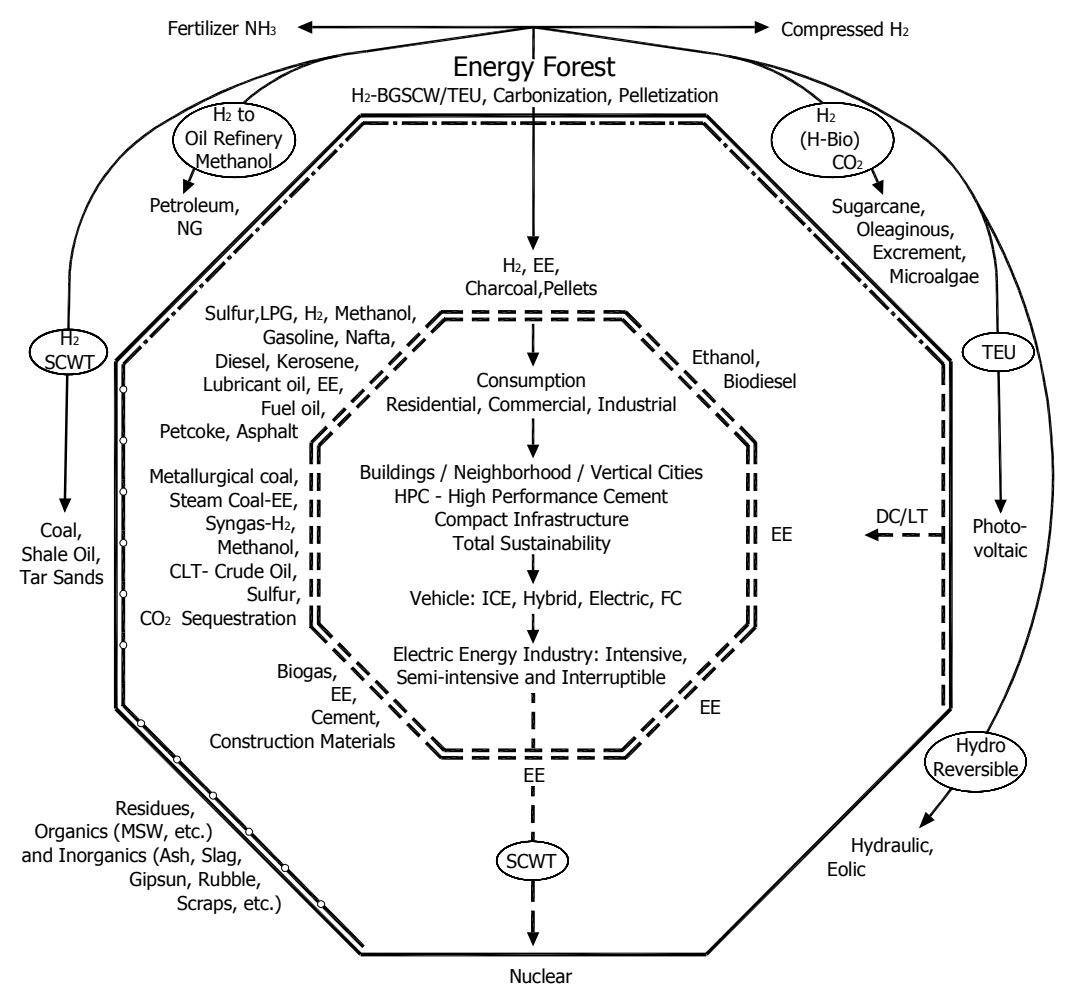

Legend:

$\mathrm{EE}$ - Electric Energy

AC/HT - Alternate Current /High Tension

DC/LT - Direct Current/Low Tension

BGSCW - Biomass Gasification in Supercritical Water

TEU - Thermoelectric Unit

ICE - Internal Engine Combustion

CTL - Coal-to-Liquid

SCWT - Supercritical Water Technology

MSW - Municipal Solid Waste

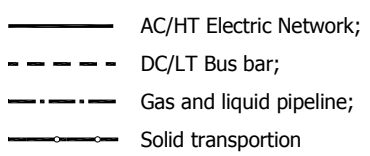

1 Integration Technology

$\mathrm{H}_{2}$ Application

Present: $\mathrm{NH}_{3}(53 \%)$; Refinery (28\%); Methanol (11\%); Compressed $\mathrm{H}_{2}(8 \%)$

Future: H-Bio; FC - Fuel Cell; Metallurgy; Other

Fig. 1. Octagonal structure of main energies: sources (outer), consumption (inner) and vectors (intermediate)

Biomass has high growth rate in the tropics, and northern hemisphere has high energy consumption suggesting to produce biomass pellets mainly in the south and export them to the north. For an expected production of $0.1 \mathrm{~kg}$ $\mathrm{H}_{2} / \mathrm{kg}$ DB (dry biomass), and 40 TDB/ha.y (whole tree)[10] the economical value is US $12,000 /$ ha.y, which allows good remuneration for high efficient biomass production. Diluted acidic prehydrolysis $\left(2 \% \mathrm{~m} / \mathrm{m} \mathrm{H}_{2} \mathrm{SO}_{4}\right.$, $\left.0.8 \mathrm{MPa}, 180{ }^{\circ} \mathrm{C}, 30 \mathrm{~min}.\right)[11]-[13]$ converts $20 \%$ of the biomass (hemicellulose) into a sugar solution (for ethanol production) and $80 \%$ into $\mathrm{CL}$ (cellulose + lignin $\mathrm{CH}_{1.363} \mathrm{O}_{0.524}, 55.2 \% \mathrm{~m} / \mathrm{m}$ of $\mathrm{C}$, compressed specific mass $=1250 \mathrm{~kg} / \mathrm{m}^{3}$, which contains $0.69 \mathrm{tC} / \mathrm{m}^{3}$ ). Table I shows TIRFE calculations in four columns: $1^{\text {st }}$ ) fossil fuel with some parameters; $2^{\text {nd }}$ ) consumption $(\mathrm{C})$, reserve lifetime (RLT) and carbon emissions (E); $3^{\text {rd }}$ ) CL stockpile (CLSP) volume/y (CLV), and forest area for residue supply (16TDB/ha.y) for CL production (FAR); $\left.4^{\text {th }}\right) \mathrm{H}_{2} / y$ production from stem forest- $\mathrm{H}_{2} \mathrm{SF}-(24 \mathrm{TDB} / \mathrm{ha}$.y, $\left.100 \mathrm{kgH}_{2} / \mathrm{TDB}\right), \mathrm{H}_{2} / \mathrm{y}$ demand for petroleum refinery$\mathrm{H}_{2} \mathrm{PR}-\left(51.5 \mathrm{kgH}_{2} / \mathrm{b}\right)[14]$ and $\mathrm{H}_{2} / \mathrm{y}$ deficiency for methanol production from coal $\left(\mathrm{H}_{2} \mathrm{Coal}\right)$. Petroleum estimated reserves are 2.5 times larger[15]. (See Further Information for Table I (a) to (j) calculations).

FAR $=1.30 \times 10^{9}$ ha $=13 \times 10^{6} \mathrm{~km}^{2}$ should not use the world agrarian land $\left(13.5 \times 10^{6} \mathrm{~km}^{2}\right)$ but only $17 \%$ of the world non agrarian occupable land $\left(76.5 \times 10^{6} \mathrm{~km}^{2}\right)$. FAR is constant and will supply residues for CLSP during RLT of fossil fuels. The area/y to be occupied by CLSP of $50 \mathrm{~m}$ high is $\left(13.34 \times 10^{9} \mathrm{~m}^{3} / \mathrm{y}\right) / 50 \mathrm{~m}=266.8 \mathrm{~km}^{2} / \mathrm{y}$ that, even if RLT is considered, it is a small area for total retention of fossil C, and is distributed all over the world. Both areas (FAR and CLSP) may be smaller due to the growth of renewables replacing fossils, better energy efficiencies, and due to the contribution of the basket of $\mathrm{CO}_{2}$ sequestration (exhausted wells of $\mathrm{P} \& \mathrm{G}$ and underground saline water). On the other hand, new discoveries of fossil fuels will increase both areas. Technological developments, cost reduction, market and environmental disasters will define the equilibrium point. CLSP has many advantages: it has $\mathrm{pH} \leq 4$ to avoid CL biological degradation; it is self-supporting up to hundreds of meters high, demanding only top and lateral impermeabilization; its top can support a solar farm installation; reforestation cost is mainly covered by the noble applications of stems (cellulose, MDF, solid wood, $\mathrm{H}_{2}$ ); sugar solution for ethanol production helps to remunerate prehydrolysis costs; profitable oil and coal used anywhere can pay a sequestration fee; CLSP is a reservoir acting as an energy security; the surface density in tC/ha is 345,000 compared

Table I. - Conversion of fossil into renewable carbon, and supplying of $\mathrm{H}_{2}$ from biomass to clean fossil fuels

\begin{tabular}{|c|c|c|c|}
\hline $\begin{array}{c}\text { Proved } \\
\text { Fossil } \\
\text { Fuels[16] }\end{array}$ & $\begin{array}{c}\text { C, } 10^{9} \\
\text { RLT, } 10^{9} \\
\text { E, } 10^{9}\end{array}$ & $\begin{array}{l}\text { CLV }, 10^{9} \\
\text { FAR, } 10^{9}\end{array}$ & $\begin{array}{c}\mathrm{H}_{2} \mathrm{SF}, 10^{9} \\
\mathrm{H}_{2}-\mathrm{PR},- \text { Coal, } 10^{9}\end{array}$ \\
\hline $\begin{array}{l}\text { Petroleum } \\
b=159 \mathrm{~L} \\
\rho=0.85 \mathrm{~kg} / \mathrm{L} \\
85 \% \mathrm{C} \mathrm{m} / \mathrm{m}\end{array}$ & $\begin{array}{c}31.0 \mathrm{~b} / \mathrm{y} \\
64.5 \mathrm{y} \\
3.56 \mathrm{tC} / \mathrm{y}\end{array}$ & $\begin{array}{c}5.16 \mathrm{~m}^{3} / \mathrm{y}(\mathrm{a}) \\
0.50 \mathrm{ha}(\mathrm{b})\end{array}$ & $\begin{array}{l}1210 \mathrm{kgH}_{2} / \mathrm{y}(\mathrm{c}) \\
1597 \mathrm{kgH}_{2} / \mathrm{y}(\mathrm{d})\end{array}$ \\
\hline $\begin{array}{l}\mathrm{NG} \\
\rho=0.65 \mathrm{~kg} / \mathrm{m}^{3} \\
75 \% \mathrm{C} \mathrm{m} / \mathrm{m}\end{array}$ & $\begin{array}{c}2770 \mathrm{~m}^{3} / \mathrm{y} \\
65.0 \mathrm{y} \\
1.35 \mathrm{tC} / \mathrm{y}\end{array}$ & $\begin{array}{c}1.96 \mathrm{~m}^{3} / \mathrm{y}(\mathrm{e}) \\
0.19 \mathrm{ha}(\mathrm{f})\end{array}$ & $\begin{array}{c}\text { NG does not } \\
\text { use } \mathrm{H}_{2}\end{array}$ \\
\hline $\begin{array}{l}\text { Coal } \\
\rho=1.3 \mathrm{t} / \mathrm{m}^{3} \\
78 \% \mathrm{C} \mathrm{m} / \mathrm{m}\end{array}$ & $\begin{array}{c}5.5 \mathrm{t} / \mathrm{y} \\
165.3 \mathrm{y} \\
4.29 \mathrm{tC} / \mathrm{y}\end{array}$ & $\begin{array}{c}6.22 \mathrm{~m}^{3} / \mathrm{y}(\mathrm{g}) \\
0.61 \mathrm{ha}(\mathrm{h})\end{array}$ & $\begin{array}{c}1457 \mathrm{kgH}_{2} / \mathrm{y}(\mathrm{i}) \\
953 \mathrm{kgH}_{2} / \mathrm{y}(\mathrm{j})\end{array}$ \\
\hline Totals & $\mathrm{C}=9.2 \mathrm{tC} / \mathrm{y}$ & $\begin{array}{c}\mathrm{CLV}= \\
13.34 \mathrm{~m}^{3} / \mathrm{y} \\
\mathrm{FAR}= \\
1.30 \mathrm{ha}\end{array}$ & $\begin{array}{c}\mathrm{H}_{2} \mathrm{SF}= \\
2667 \mathrm{kgH}_{2} / \mathrm{y} \\
\mathrm{H}_{2}-\mathrm{PR},-\mathrm{Coal}= \\
2550 \mathrm{kgH}_{2} / \mathrm{y}\end{array}$ \\
\hline
\end{tabular}


with tropical forest, which is 240 . There is a balance between supply of $\mathrm{H}_{2} \mathrm{SF}$ and demand of $\mathrm{H}_{2}-\mathrm{PR}$,-Coal but not all stem will be transformed into $\mathrm{H}_{2}$, neither all coal into methanol.

Oil from oleaginous, microalgae and excretion can be transformed into biodiesel by $\mathrm{H}$-Bio process. H-Bio will impact three areas: preservation of Amazon and other biomes by extractive technologies; retention of $\mathrm{CO}_{2}$ via microalgae growth in photobioreactors; conversion of excretion into char and oil by LTC (low temperature conversion)[17]. An example of the last one is the transformation of inefficient extensive into intensive cattle farms $\left(200 \times 10^{6}\right.$ herds in Brazil), which allows collection and processing of the excretion yielding biodiesel close to the present diesel consumption in Brazil $\left(52 \times 10^{9} \mathrm{~L} / \mathrm{y}\right)[16]$.

\section{Integration through supercritical water technology (SCWT) and electric energy}

High purity SCW is a great success in FPP (fossil power plant, $\eta=40-49 \%)[18],[19]$ and is being expanded to nuclear and biomass power plants[20],[21]. That technology (water purity, materials, piping, valves, turbines) will be adopted for the TEU circuit of $\mathrm{H}_{2}$-BGSCW/TEU. However, the second circuit of the $\mathrm{H}_{2}$ production, which uses $5 \% \mathrm{~m} / \mathrm{m}$ of biomass slurry, has problems of materials, energy recovery, plugging, corrosion, size of research facilities and economics that are minimized by the integration of SCWT and EE. Before description of $\mathrm{H}_{2}$-BGSCW/TEU (cf. Item 5) we will point out the optimization of urban energy use.

Optimization of urban occupation in integrated vertical cities - IVC $\left(50,000\right.$ inhab. $/ \mathrm{km}^{2}$ in12-floor buildings with 3-floor garages and 9-floor of residences or commercial offices) reduces $8 \mathrm{~km}^{2}$ from the horizontal city configuration. IVC can be supplied with $2460 \mathrm{kWh} /$ inhab.y from solar panels installed at the top of the buildings and streets, and with $1440 \mathrm{kWh} / \mathrm{inhab} . \mathrm{y}$ from $\mathrm{H}_{2}$-BGSCW/TEU (CHP fuelled by forest pellets of an equivalent area not occupied by the horizontal city) totalizing $3900 \mathrm{kWh} / \mathrm{inh}$ ab.y, which is almost the double of the total Brazilian electric energy consumption of $2117 \mathrm{kWh} /$ inhab.y, and a half or a third of developed countries, to be supplied with fossil energy[22]. IVC avoid occupation of agrarian and forestry areas and have lower cost of infrastructure (street, water supply, sewage treatment, electrical network), car traffic, travelling time.

There is room for future integration of SMES (superconductor magnet energy storage) for improvement of energy quality, power factor and peak energy supply of a system of multiple and intermitent sources[23]. Solar panels, electrical battery recharge and SMES form a DC/LT local network integrated with AC/HT network substation with an AC/DC converter.

\section{Integration through organic and inorganic residues}

Organic residues and herbaceous, when sufficiently clean, will be directed to the $\mathrm{H}_{2}$-BGSCW/TEU together with the wood stem. Unclean residues will be directed to the fluidized bed (or grate) furnace. Examples of the last ones are: MSW, dry sludge, industrial organic residues, grass, agricultural waste, petcoke, and forest residues.

Inorganic impurities are not dissolved in the SCW and tend to form crystallites (hydrothermal synthesis) that should be filtered after the heat exchange. The first objective of hydrothermal synthesis is to recover $\mathrm{K}, \mathrm{P}$ (fertilizers) but SCW technology can be improved to simultaneously produce high-tech materials [24], $\mathrm{H}_{2}$ and EE.

Production processes of inorganic materials are large consumers of energy (steels, non ferrous metals, cement, etc.). The low resistance of bricks (4 MPa) and common cement (30 MPa) leads to horizontal cities. Table II gives the traces of common concretes-CC, and high performance concrete - HPC[25]. Some comments can be made about them.

Table II. Traces of two types of concretes, in $\mathrm{kg} / \mathrm{m}^{3}$

\begin{tabular}{ccccccccc}
\hline $\mathrm{T}$ & $\mathrm{C}$ & $\mathrm{AG}$ & $\mathrm{S}$ & $\mathrm{AS}$ & $\mathrm{SP}$ & $\mathrm{W}$ & $\mathrm{W} /$ & $\sigma$, \\
$(1)$ & $(2)$ & $(3)$ & $(4)$ & $(5)$ & $(6)$ & $(7)$ & $\mathrm{C}+\mathrm{S}$ & $\mathrm{MPa}$ \\
\hline $\mathrm{CC}$ & 400 & 1100 & 861 & -- & 2 & 172 & 0.43 & 42 \\
$\mathrm{HPC}$ & 435 & 1000 & 620 & 95 & 7.5 & 173 & 0.33 & 85 \\
${ }^{1}$ Trace & ${ }^{2}$ Cement & ${ }^{3}$ Aggregate & ${ }^{4}$ Sand & ${ }^{5}$ Active rice husk & silica \\
(RHS) & ${ }^{6}$ Superplastificant ${ }^{7}$ Water & $\sigma=$ Compression resistance
\end{tabular}

The active silica in HPC was obtained from rice husk burned at $\mathrm{T}<800{ }^{\circ} \mathrm{C}$ in a fluidized bed boiler of a TEU (5 MW) with the following composition $(\% \mathrm{~m} / \mathrm{m})$ and characteristics: $\mathrm{SiO}_{2}$ (93.43), $\mathrm{K}_{2} \mathrm{O}$ (1.22), $\mathrm{P}_{2} \mathrm{O}_{5}$ (0.37), $\mathrm{CaO}$ (0.31), $\mathrm{MgO}(0.27), \mathrm{MnO}(0.26)$, other (0.15), LOI 3.99), BET specific surface $32 \mathrm{~m}^{2} / \mathrm{g}$, particle size $<100 \mu \mathrm{m}$ [25].

HPC is used for expensive large constructions (tower buildings, bridges, dams, ports, ocean platforms, etc.) but plate development is under way for floor/ceiling and wall/pillar casted in factories followed by IVC assembling, with the same cost of the low-cost horizontal cities, and prepared to receive photovoltaic panels.

HPC (90 MPa, $2500 \mathrm{~kg} / \mathrm{m}^{3}$ ) replaces structural steels (280 MPa, $7600 \mathrm{~kg} / \mathrm{m}^{3}$ ) because their ratios of strengths and specific masses are equal to 3.1. Reactive powder concrete-RPC (400 to $800 \mathrm{MPa}$ ) replaces high strength steel in mechanical engineering.

\section{Evolution of the $\mathrm{H}_{2}$-BGSCW/TEU concept}

$\mathrm{H}_{2}$-BGSCW/TEU shown in Fig. 2 is the proposed technology to promote TIRFE. A brief description of each sector is given below. 


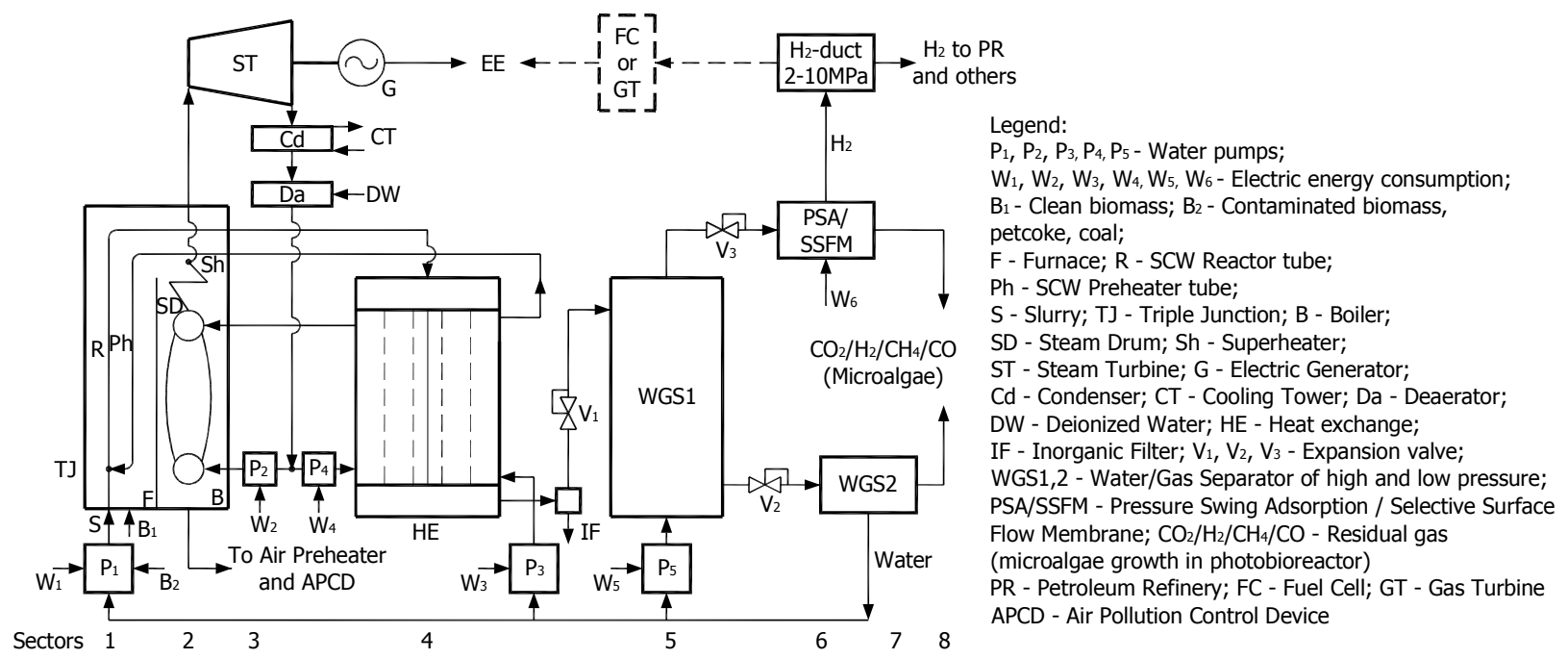

Fig 2. Flow chart of $\mathrm{H}_{2}$-BGSCW/TEU

Sector 1: thermally isolated furnace similar to the petrochemical pyrolysis of ethylene $\left(\mathrm{C}_{2} \mathrm{H}_{2}\right)[26]$ and reforming of $\mathrm{H}_{2}$ production[27]. It comprises the SCW reactor and preheater tubes (SCWRPh), which are heated by burning unclean fuels (fluidized bed or grate). Lifetime greater than 6 years of improved centrifuged heat resistant steel tubes (similar to petrochemical furnaces) is economically acceptable for TIRFE because of their large scale production and scrap remelting. Clean biomass (woody, herbaceous) is pumped into SCWRPh by a slurry pump $(30 \%$ of $\mathrm{DB}) . \mathrm{H}_{2}$ production rates at $25 \mathrm{MPa}$, $650{ }^{\circ} \mathrm{C}$ are, in $\mathrm{kg} \mathrm{H}_{2} / \mathrm{kg} \mathrm{DB}: 0.177$ (theoretical), 0.166 (thermodynamic) and 0.100 (practical, with activated carbon as a catalyst). At the triple junction $\mathrm{S} / \mathrm{Ph} / \mathrm{R}$ the slurry must receive a thermal shock to $650{ }^{\circ} \mathrm{C}$ to minimize incrustation of furfural/phenol that will be periodically burned in a similar way to the petrochemical furnaces (4 days/month). Parameters of this sector are:

Tubes: alloy $\mathrm{Cr} 25 \mathrm{Ni} 35 \mathrm{NbY}$, alloy specific mass $\rho=$ $8000 \mathrm{~kg} / \mathrm{m}^{3}$, creep strength at $10^{5} \mathrm{~h} / 875{ }^{\circ} \mathrm{C}=82 \mathrm{MPa}$, admissible strength $\sigma=41 \mathrm{MPa}$, inner diameter $100 \mathrm{~mm}$, thickness $\mathrm{t}=30 \mathrm{~mm}$, length $=12 \mathrm{~m}, \mathrm{SCW}$ pressure $\mathrm{P}=$ $25 \mathrm{MPa}$, specific weight $\mathrm{w}=100 \mathrm{~kg} / \mathrm{m}$, average alloy price US $25.50 / \mathrm{kg}$ (US $2550 / \mathrm{m}$ ). $\mathrm{P} / \sigma$ ratio is critical for lowering $\mathrm{w}$ and tube cost (Eq. (1) and (2)):

$$
P d=2 \sigma t(1)
$$

$$
w=\pi(d+t)=\left(\pi d^{2} / 4\right)(2+P / \sigma)(P / \sigma) \rho
$$

Reactor tube mass flows: SCW specific mass $\rho=64.8 \mathrm{~kg} / \mathrm{m}^{3}$, residence time $\Delta \mathrm{t}=30 \mathrm{~s}=0.00833 \mathrm{~h}(\mathrm{Eq}$. (3) to (6)):

$$
\begin{gathered}
\dot{m}_{\text {Reactor }}=\left(\pi d^{2} / 4\right) L \rho_{S C W} / \Delta t=732.8 \mathrm{~kg} / \mathrm{h} \\
\dot{m}_{\text {Biomass }}=0.05 \times \dot{m}_{\text {Reactor }}=36.6 \mathrm{~kg} \mathrm{DB} / \mathrm{h} \\
\dot{m}_{\text {Slurry }(30 \% D B)}=\dot{m}_{\text {Biomass }} / 0.3=122.1 \mathrm{~kg} / \mathrm{h}
\end{gathered}
$$

$$
\begin{aligned}
\dot{m}_{H_{2}} & =0.1 \mathrm{~kg} / \mathrm{kg} \mathrm{DB} \times 36.6 \mathrm{~kg} \mathrm{DB} / \mathrm{h}= \\
& =3.66 \mathrm{~kg} \mathrm{H} / \mathrm{h} . \mathrm{tube}
\end{aligned}
$$

Preheater tube parameters are calculated from mass and enthalpy balance at the TJ (Eq. (7) and (8)):

$$
\begin{aligned}
& \dot{m}_{\text {Preheater }}=\dot{m}_{\text {Reactor }}-\dot{m}_{\text {Slurry }}=610.43 \mathrm{~kg} / \mathrm{h} \\
& \dot{m}_{\text {Preheater }} h_{\text {Preheater }}=\dot{m}_{\text {Reactor }} h_{\text {Reactor }}-\dot{m}_{\text {Slurry }} h_{\text {Slurry }}
\end{aligned}
$$

where $\mathrm{h}_{\text {Reactor }}=3637.7 \mathrm{~kJ} / \mathrm{kg} \quad(\mathrm{SCW}, \mathrm{P}=25 \mathrm{MPa}$, $\mathrm{T}=650{ }^{\circ} \mathrm{C}$ ) and $\mathrm{h}_{\text {Slurry }}=1707.9 \mathrm{~kJ} / \mathrm{kg}$ (compressed water, $\left.\mathrm{P}=25 \mathrm{MPa}, \mathrm{T}=360{ }^{\circ} \mathrm{C}\right)$, resulting in $\mathrm{h}_{\text {Preheater }}=$ $4005.7 \mathrm{~kJ} / \mathrm{kg}$ and $\mathrm{T}_{\text {Preheater }}=785.8{ }^{\circ} \mathrm{C}$.

In petrochemical furnaces tubes work at higher temperature and lower pressure $\left(1100{ }^{\circ} \mathrm{C}, 4 \mathrm{MPa}\right)$ when compared to $\mathrm{H}_{2}$-BGSCW, which works at lower temperature and higher pressure $\left(875^{\circ} \mathrm{C}, 25 \mathrm{MPa}\right)$. These conditions reduce creep and carbonization but increase corrosion with predominance of oxidation in austenitic alloys exposed to SCW. Data of $800 \mathrm{H}$ alloy (Fe21Cr32Ni) with grain boundary engineering for $1000 \mathrm{~h}$ have a weight change of $0.16 \mu \mathrm{m} / \mathrm{y}$ at $500{ }^{\circ} \mathrm{C}$ and $0.27 \mu \mathrm{m} / \mathrm{y}$ at $600{ }^{\circ} \mathrm{C}$ [28]. Extrapolation to $800{ }^{\circ} \mathrm{C}$ yields $0.49 \mu \mathrm{m} / \mathrm{y}$ and, even with higher corrosion rate due to organic and inorganic impurities, it will allow a 6-year tube lifetime or more for the thermochemical furnace. In FPP corrosion rates are smaller because of the clean SCW, reaching 40-year lifetime.

Sectors 2 and 3: TEU will follow reference technologies, such as FPP 430 MWe, 1000 MWt, 540/560 ${ }^{\circ} \mathrm{C}$, $\mathrm{P}=25 \mathrm{MPa}, \mathrm{d}=221 \mathrm{~mm}, \mathrm{t}=32 \mathrm{~mm}, \mathrm{w}=203.4 \mathrm{~kg} / \mathrm{m}$, alloy P91, $\sigma\left(10^{5} \mathrm{~h}\right)=175 \mathrm{MPa}, \sigma=86.3 \mathrm{MPa}$, alloy price US 7.60/kg (US 1546.00/m)[18],[19]. Second generation of $\mathrm{H}_{2}$-BGSCW/TEU may follow reference AD700 technology parameters: $700 / 720{ }^{\circ} \mathrm{C}, \quad \mathrm{P}=35 \mathrm{MPa}$, $\mathrm{d}=175 \mathrm{~mm}, \mathrm{t}=60 \mathrm{~mm}, \mathrm{w}=354.2 \mathrm{~kg} / \mathrm{m}$, A617 alloy, $\sigma\left(10^{5} \mathrm{~h}\right)=100 \mathrm{MPa}, \sigma=51.0 \mathrm{MPa}$, alloy price US $66.60 / \mathrm{kg}$ (US 23,520.00/m) [18],[19]. 
Sector 4: shell tube heat exchange has three fluxes: SCW with gases coming from reactor tube $\left(650^{\circ} \mathrm{C}\right)$ cooled to $60{ }^{\circ} \mathrm{C}$, passing through IF and going to the high pressure expansion valve V1 (25 to $12 \mathrm{MPa}$ ); cold water $\left(40{ }^{\circ} \mathrm{C}\right)$ pumped by $\mathrm{P} 3$, heated to $600{ }^{\circ} \mathrm{C}$, and going to the preheater; cold water $\left(40{ }^{\circ} \mathrm{C}\right)$ pumped by $\mathrm{P} 4$ from the deaerator of TEU circuit, cooling the shell of the heat exchange and returning to TEU circuit as saturated steam. Details of this sector will be published elsewhere.

Sectors 5, 6 and 7: water/gas separators PSA/SSFM follow conventional technology of TEU and of industrial gas technology, and will not be described here. $\mathrm{H}_{2}$ is generated at high pressure and its recovery can be increased with membrane developments.

Sector 8: microalgae growth in photobioreactors is in rapid development and will be added to TIRFE when $\mathrm{H}_{2}$-BGSCW/TEU plants are installed. Besides oil and protein, this sector generates $\mathrm{O}_{2}$ enriched air to be used in the furnace to efficiently burn unclean fuels.

The $\mathrm{H}_{2}$-BGSCW/TEU has possibilities of regulation and storage of energy: decrease of $\mathrm{H}_{2}$ production (endothermic heat absorption) and increase of EE production; storage into $\mathrm{H}_{2}$-ducts (pressure between 2 and $10 \mathrm{MPa}$ ) and in methanol from coal; future use of $\mathrm{H}_{2}$ gas in stationary and mobile fuel cells, the last one by reforming of methanol in cartridges.

The present paper is the first part of a second one, which will detail the design of the pilot plant including energy and mass balance, regulation and storage capacity via $\mathrm{H}_{2} /$ EE/methanol production, and economical analysis.

\section{Economical considerations}

TIRFE uses proved and economic technologies of the following sectors: high productivity forest in world available areas (greening), exportation of wood pellets, materials and processes from petrochemical pyrolysis and reforming, SCW-FPP, industrial gases, $\mathrm{H}_{2}$ supply to PR, $\mathrm{H}_{2}$ deficiency supply to methanol from coal, HPC with RHS to reduce price of vertical buildings and viaducts allowing optimization of IVC, elimination of land and land preparation cost for solar energy farms and integration of solar energy/ CHP / swapple electric car batteries in a local DC/LT network with connection with centralized sources (hydro, thermal, eolic, nuclear) by $\mathrm{AC} / \mathrm{HT}$ substation with an AC/DC converter.

It remains to be effected the industrial production rate of $0.1 \mathrm{tH}_{2} / \mathrm{TDB}$ by $\mathrm{H}_{2}$-BGSCW, and CLSP for carbon retention. The last one can have the following economical contributions: $20 \%$ of ethanol from sugar solution from prehydrolysys, $35 \%$ from solar farm revenues at the top of CLSP, $5 \%$ fees from oil and $25 \%$ of CL heating value as energy security cost totalizing US $80.90 / \mathrm{tC}$. This value results in US $22.10 / \mathrm{tCO}_{2}$ and US $44.70 / \mathrm{tCL}$, sufficient to cover costs of local forest residue transportation, prehydrolysis and CLSP formation. Detailed economic analysis will be published eslsewhere.

\section{Further information}

Table I calculations (a) to (j).

a. $\left(3.56 \times 10^{9} \mathrm{tC} / \mathrm{y}\right) /\left(0.69 \mathrm{tC} / \mathrm{m}^{3} \mathrm{CL}\right)=5.16 \times 10^{9} \mathrm{~m}^{3} / \mathrm{y}$

b. $\left(5.16 \times 10^{9} \mathrm{~m}^{3} / \mathrm{y} \quad \mathrm{x} \quad 1.25 \mathrm{tCL} / \mathrm{m}^{3}\right) /(0.8 \mathrm{tCL} / \mathrm{TDB} \quad \mathrm{x}$

$\mathrm{x} 16 \mathrm{TDB} / \mathrm{ha} . \mathrm{y})=0.504 \times 10^{9} \mathrm{ha}=5.0 \times 10^{6} \mathrm{~km}^{2}$

c. $\left(0.504 \times 10^{9}\right.$ ha $\times 24$ TDB/ha.y $) \times 100 \mathrm{~kg} \mathrm{H} \mathrm{H}_{2} / \mathrm{TDB}=$ $=1209 \times 10^{9} \mathrm{~kg} \mathrm{H}_{2} / \mathrm{y}$

d. $31.0 \times 10^{9} \mathrm{~b} / \mathrm{y} \times 51.5 \mathrm{kgH}_{2} / \mathrm{b}=1596.5 \times 10^{9} \mathrm{kgH}_{2} / \mathrm{y}$

e. $\left(1.35 \times 10^{9} \mathrm{tC} / \mathrm{y}\right) /\left(0.69 \mathrm{tC} / \mathrm{m}^{3} \mathrm{CL}\right)=1.96 \times 10^{9} \mathrm{~m}^{3} / \mathrm{y}$

f. $\left(1.96 \times 10^{9} \mathrm{~m}^{3} / \mathrm{y} \quad \mathrm{x} \quad 1.25 \mathrm{tCL} / \mathrm{m}^{3}\right) /(0.8 \mathrm{tCL} / \mathrm{TDB} \quad \mathrm{x}$

$\mathrm{x} 16 \mathrm{TDB} / \mathrm{ha} . \mathrm{y})=0.191 \times 10^{9} \mathrm{ha}=1.91 \times 10^{6} \mathrm{~km}^{2}$

g. $\left(4.29 \times 10^{9} \mathrm{tC} / \mathrm{y}\right) /\left(0.69 \mathrm{tC} / \mathrm{m}^{3} \mathrm{CL}\right)=6.22 \times 10^{9} \mathrm{~m}^{3} / \mathrm{y}$

h. $\left(6.22 \times 10^{9} \mathrm{~m}^{3} / \mathrm{y} \quad \mathrm{x} \quad 1.25 \mathrm{tCL} / \mathrm{m}^{3}\right) /(0.8 \mathrm{tCL} / \mathrm{TDB} \quad \mathrm{x}$ $\mathrm{x} 16 \mathrm{TDB} / \mathrm{ha} . \mathrm{y})=0.607 \times 10^{9} \mathrm{ha}=6.1 \times 10^{6} \mathrm{~km}^{2}$

i. $0.607 \times 10^{9}$ ha $\times 24$ TDB/ha.y $\times 100 \mathrm{~kg} \mathrm{H} / \mathrm{TDB}=$ $=1456.8 \times 10^{9} \mathrm{~kg} \mathrm{H}_{2} / \mathrm{y}$

j. $\mathrm{H}_{2}$ deficiency for methanol production from coal

$\left(\mathrm{C}+2 / 3 \mathrm{H}_{2} \mathrm{O}+1 / 6 \mathrm{O}_{2}\right)_{\text {coal }}+\left(4 / 3 \mathrm{H}_{2}\right)_{\text {biomass }}=\mathrm{CO}+2 \mathrm{H}_{2} \rightarrow \mathrm{CH}_{3} \mathrm{OH}$

$4.29 \times 10^{9} \mathrm{tC} / \mathrm{y} \times\left(8 / 3 \mathrm{gH}_{2}\right) \times(1 / 12 \mathrm{gC})=953.3 \times 10^{9} \mathrm{~kg} \mathrm{H}_{2} / \mathrm{y}$

Biodiesel production from excretion by LTC $\left(200 \times 10^{6}\right.$ herds)

$5 \mathrm{~kg}$ DM excretion/d.herd x $365 \mathrm{~d} / \mathrm{y} \times 200 \times 10^{6}$ herds $\mathrm{x}$ $12 \%$ LTC oil conversion $/ 0.85 \mathrm{~kg} / \mathrm{L}=52 \times 10^{9} \mathrm{~L} / \mathrm{y}$

IVC solar panel electric energy/inhab.y

[4.8 $\mathrm{kWh} / \mathrm{m}^{2}$.d (daily sun stroke) x $18 \%$ (photovoltaic efficiency) $\times 10^{6} \mathrm{~m}^{2} / \mathrm{km}^{2} \times 60 \%$ (area coverage) $\times 365 \mathrm{~d} / \mathrm{y}$ x $65 \%$ (sunny day/y)] $/\left(50,000\right.$ inhab. $\left./ \mathrm{km}^{2}\right)=$ $=2460 \mathrm{kWh} /$ inhab.y

UTE energy supply/inhab.y fuelled by a forest of $8 \mathrm{~km}^{2}$ equals to an area not occupied by a horizontal city

$\left[8 \mathrm{~km}^{2}\right.$ x $100 \mathrm{ha} / \mathrm{km}^{2}$ x 40 TDB/ha.y $\times 10^{3} \mathrm{~kg} / \mathrm{t} \quad \mathrm{x}$ $18.4 \mathrm{MJ} / \mathrm{kg}$ x $44 \%$ (thermoelectric efficiency) x $1 \mathrm{~h}] /(3600$ s x 50,000 inhab.) $=1439 \mathrm{kWh} /$ inhab.y

\section{Conclusion}

TIRFE concept proves that it is possible to simultaneously supply world energy demand with emission cleaning, retention of GHG from fossil fuels by reforestation and CLSP, helped by a basket of technologies, aiming to conversion of fossil into renewable carbon. TIRFE is better expressed by three concentric octagons of energies: consumption (inner), vectors (EE, gas, liquid and solid) (intermediate), and sources (outer). TIRFE fulfils all energy criteria such as quantity, quality, security, economical feasibility, availability of technology for the first generation, and organization of the next generation.

The most effective technology is the combined cycle $\mathrm{H}_{2}$-BGSCW/TEU generating $\mathrm{H}_{2} / \mathrm{EE}$ that complements and/or competes with the conventional syngas production plus water shift. Improved heat resistant steels allow SCW installations with an EE efficiency of 40 to $49 \%$, plus the $\mathrm{H}_{2}$ production not yet industrialized. The tendency to the Carnot cycle $\left(\mathrm{T}_{\mathrm{H}}=1000 \mathrm{~K}, \mathrm{~T}_{\mathrm{L}}=300 \mathrm{~K}, \eta=70 \%\right)$ is due to the total integration concept where losses of one player are 
recovered by the next one, and internal energy consumption is smaller (water pumping).

Short lifetime materials and equipments (> 6 years), similar to the petrochemical furnaces, will be used in the $\mathrm{H}_{2}$-BGSCW reactor/preheater, with scrap remelting. Stateof-the-art long lifetime materials/equipments (> 40 years) will be used in the remaining of the plant.

$\mathrm{H}_{2}$-BGSCW/TEU allows scale from pilot plants (distributed generation/consumption of $\mathrm{H}_{2}$ and $\mathrm{EE}$ ) up to large scale captive plants of $\mathrm{H}_{2}$. Distributed generation and consumption allows DC/LT integration with photovoltaic, electric cars, fuel cells and future SMES.

The main energy reduction at the consumption side comes from the IVC by replacement of low-strength materials (brick $4 \mathrm{MPa}, \mathrm{CC} 30 \mathrm{MPa}$ ) by factory casted HCP $90 \mathrm{MPa}$ with addition of RHS. The buildings are prepared to receive solar panels, collect rain water, treat the sewage and reuse the water.

$\mathrm{H}_{2}$-BGSCW/TEU can be installed by incremental logistic either in new or existent cities aiming to the full integration in the future. Southern/Northern hemisphere integration will be via biomass / CL pellets by technology and equipments exchange. Arguments of energy security can never ignore the sun distribution over the globe.

Preindustrial society was dependent on renewable energy (biomass, $10^{9}$ inhab., rural). Postindustrial society is dependent on fossils $\left(7 \times 10^{9}\right.$ inhab., horizontal/ tower building cities) with energy supply and GHG problems that can be solved by TIRFE whose quantitative equilibrium shown in this paper (fossil, biomass, solar, CLSP, IVC) comes from the fact that the origin of the fossils was the prehistorical renewables (solar+biomass).

\section{References}

[1] UNEP, 2011, Towards a Green Economy: Pathways to Sustainable Development and Poverty Eradication, www.unep.org/greeneconomy, accessed Jun, 2011.

[2] L. Guo, C. Cao and Y. Lu, "Supercritical Water Gasification of Biomass and Organic Wastes", in Biomass, M. Momba and F. Bux (eds), Sciyo, Croatia (2010), Ch.9, pp.165-182, www.intechopen.com, accessed Sept., 2010.

[3]Y.Lu, L.Guo, X.Zhang, Q.Yan, "Thermodynamic modeling and analysis of biomass gasification for hydrogen production in supercritical water",Chem. Eng. J.,Vol. 131, (2007), pp.233-244. [4] Y.L. Lu, L.J. Guo, C.M. Ji, X.M. Zhang, X.H. Hao and Q.H. Yan,"Hydrogen production by biomass gasification in supercritical water: a parametric study", Int. J. Hydrogen Energ., Vol. 31, (2006), pp. 822-831.

[5] M.J. Antal Jr., S.G. Allen, D. Schulman, X. Xu,"Biomass gasification in supercritical water", Ind. Eng. Chem. Res.,Vol. 39, (2000), pp. 4040-4053.

[6] Y. Guo, S.Z. Wang, D.H. Xu, Y.M. Gong, H.H. Ma and X.Y. Tang, "Review of catalytic supercritical water gasification for hydrogen production from biomass", Renew. Sust. Energ. Rev., Vol.14, (2010), pp. 334-343.

[7] Processo H-Bio, Tecnologia Petrobras para Produção de Óleo Diesel Renovável, (2007), www2.petrobras.com.br/tecnologia/port/hbio.asp, accessed Oct. 2011.
[8] G.A. Olah, A. Goeppert, G.K.S. Prakash,"Beyond Oil and Gas: The Methanol Economy",Wiley, Weinheim (2006), 290 pp. [9] K.G. Satyanarayana, A.B. Mariano and J.V.C. Vargas, "A review on microalgae, a versatile source for sustainable energy and materials", Int. J. Energy Res., (2011), pp. 291-311.

[10] L.G. Brandão, Y.K. Ikemori and E. Campinhos Jr., in Proc. of "The new eucalypt forest: lectures given by the 1984 Marcus Wallenberg prize winners", Falun, (1984), 29 pp.

[11] D.G. Pinatti, C. A.Vieira, A. G. Soares, "Catalytic Cellulignin Fuel," 2005, Feb. 15, U.S.Patent 6,855,180B1.

[12] M. Tampier, P.A. Beauchemin, D. Smith and E. Bibeau, "Identifying Environmentally Preferable Uses for Biomass Resources-BC Bugwood: Economics, Technical Feasibility and GHG Implications of Seven Small to Medium-Scale Technologies", Environchem Services Inc., North Vancouver, (2006), Ch.4, pp.22-37.

[13] D.G. Pinatti, R.A. Conte, A.G. Soares, M.L.G. Pereira, E.L. Romão, J.C. Ferreira, I. Oliveira and L.F.M. Marton, "Biomass Refinery as a Renewable Complement to the Petroleum Refinery", Int. J. Chem. Reactor Eng.,Vol.8, (2010), A94,17 pp.

[14] F. Self, E. Ekholm and K. Bowers, "Refining OverviewPetroleum, Process and Products", American Institute of Chemical Engineering, Texas, (2000), Ch.26, pp.1-7.

[15] D. Yergin, "The Quest - Energy, Security and the Remaking of the Modern World", Penguin Books, London (2011), 816 pp.

[16] "Plano Nacional de Energia 2030", Empresa de Pesquisa Energética, Ministério de Minas e Energia, Brasília (2007), www.epe.gov.br, accessed Sept., 2011.

[17] D.G. Pinatti, I. Oliveira, A.G. Soares, E.L. Romão and J.C. Ferreira,"Aparelho e Processo para Decomposição de Qualquer Tipo de Material Orgânico",(2008), Brazilian PI 0804349-3, Oct. 16, 2008.

[18] Fossil Fuel Power Generation-State-of-the-Art, Power Clean Thematic Network, (2004), 75 pp. http://www.irc.ee/6rp/valdkonnad/P6/energia/Powerclean state of the art final.pdf, accessed Oct. 2011.

[19] H. Tschaffon, "700 ${ }^{\circ} \mathrm{C}$ Power Plant Technology - Status and Challenge", in Proc. of $9^{\text {th }}$ Liege Conference: Materials for Advanced Power Engineering, (2010), pp. 20-28.

[20] V. Tulkki, "Supercritical water reactors: a survey on international state of research in 2006", Master Thesis, Helsinki University of Technology, Otaniemi, (2006), $91 \mathrm{pp}$.

[21] P. Henderson and A. Hjörnhede, "Combating corrosion in biomass and waste fired plant", in Proc. of $9^{\text {th }}$ Liege Conference: Materials for Advanced Power Engineering,(2010), pp. 962-975. [22] Energy Statistics $>$ Electricity $>$ consumption(per capita/y), CIA World Factbooks, http://www.nationmaster.com/graph/ene ele con percap-

energy-electricity-consumption-per-capita, accessed Sept., 2011. [23] M.R.I. Sheikh, S.M. Muyeen, R. Takahashi, and J. Tamura, "Multi-area frequency and tie-line power flow control by fuzzy grain scheduled SMES", in "Energy Storage", R.I. Sheikh (ed), Sciyo, Croatia, (2010), Ch. 5, pp. 87-102.

[24] T. Adschiri and K. Arai,"Hydrothermal synthesis of metal oxide nanoparticles under supercritical conditions", in "Supercritical Fluid Technology in Materials Science and Engineering, YA-Ping-Sun (ed), Marcel Dekker, New York, (2002), Ch. 8, 15 pp.

[25] D.G. Pinatti, L.F.M. Marton and O. Pilecco, "Processo de produção de sílica de casca de arroz fluidizada e respectivo produto resultante", (2011), Brazilian Patent Pending.

[26] L.W.O. Kneil, "Ethylene", in "Encyclopedia of Chemical Processing and Design", J. J. McKetta (ed), Marcel Dekker, New York (1984), pp. 89-125.

[27] K.Z.Patil, "Hydrogen", in Encyclopedia of Chemical Processing and Design", J. J. McKetta (ed), Marcel Dekker, New York (1987), pp. 485-497.

[28] L. Tan, T.R. Allen and Y. Yang,"Corrosion behavior of alloys $800 \mathrm{H}(\mathrm{Fe}-21 \mathrm{Cr}-32 \mathrm{Ni})$ in supercritical water", Corros. Sci., Vol. 53, (2011), pp. 703-711. 